Распространение, состояние и перспективы охраны каспийского полоза Hierophis caspius (Gmelin, 1789) (Colubridae, Reptilia) в Казахстане

\author{
К. М. Ахмеденов ${ }^{1}$, А. Г. Бакиев ${ }^{2}$, Р. А. Горелов ${ }^{2}$, Г. А. Назарова ${ }^{1}$ \\ ${ }^{\prime}$ Западно-Казахстанский государственный университет им. Махамбета Утемисова \\ Казахстан, 090000, Уральск, просп. Н. Назарбаева, 162 \\ E-mail: kazhmurat78@mail.ru \\ ${ }^{2}$ Институт экологии Волжского бассейна РАН \\ Россия, 445003, Тольятти, Комзина, 10 \\ E-mail:herpetology@list.ru
}

Поступила в редакцию 27.01.2019 г., после доработки 17.03.2019 г., принята 27.04.2019 г.

\begin{abstract}
Каспийский полоз описан И. И. Лепёхиным (1771), возможно, из Западного Казахстана. Видовое название caspius присвоил змее И. Ф. Гмелин (Gmelin, 1789). На основании собственных и литературных данных приведены современные места обитания каспийского полоза в Западно-Казахстанской и Атырауской областях Казахстана -

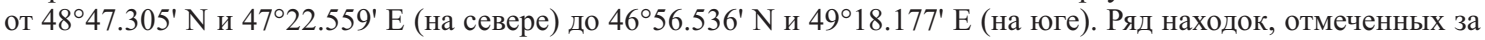
последние 250 лет в современных Курмангазинском, Исатайском и Махамбетском районах Атырауской области, а также в окрестностях г. Атырау, в Тупкараганском районе Мангистауской области, Акжаикском и Жангалинском районах Западно-Казахстанской области требуют подтверждения и уточнения. Указания на распространение вида в Восточном Казахстане ошибочны. На особо охраняемых природных территориях (ООПТ) Казахстана в настоящее время вид достоверно обитает только в государственном природном заказнике местного значения «Орда», где обнаружен в 2018 г. Для сохранения вида в Казахстане перспективным представляется обоснование и создание ООПТ «Гора Малое Богдо». На этой горе и в ее окрестностях, где начата добыча нерудных полезных ископаемых, обитают редкие виды растений и животных, в том числе каспийский полоз с относительно высоким обилием.

Ключевые слова: змеи, Красная книга Республики Казахстан, Малое Богдо, государственный природный заказник местного значения «Орда».
\end{abstract}

DOI: https://doi.org/10.18500/1814-6090-2019-19-1-2-3-16

\section{ВВЕДЕНИЕ}

В Красную книгу Республики Казахстан последнего - четвертого - издания (2010) включен «желтобрюхий полоз Coluber caspius Gmelin, 1779» (sic, на самом деле год опубликования И. Ф. Гмелиным названия Coluber caspius - 1789), относящийся к семейству ужовых змей Colubridae, со статусом «IV категория. Неизученный вид» (Брушко, Зима, 2010, с. 78). Составители видового очерка сообщают, что меры охраны желтобрюхого полоза не принимались и не разработаны по причине неизученности вида. Предложения составителей по его исследованию следующие: «Необходимо определить границы распространения и численность в Казахстане, изучить биологию» (с. 79). Желтобрюхий полоз (он же каспийский полоз) признается современными герпетологами самостоятельным монотипическим видом под латинскими названиями: Coluber caspius, Hierophis caspius, Dolichophis caspius.

Задачами настоящей статьи являются уточнение распространения, оценка состояния охраны и разработка предложений по сохранению вида в Республике Казахстан.

\section{МАТЕРИАЛ И МЕТОДЫ}

Материалом для статьи послужили полевые исследования авторов 2017 - 2018 гг. на территориях Акжаикского и Бокейординского районов Западно-Казахстанской области, Индерского и Курмангазинского районов Атырауской области Казахстана. Проанализированы литературные источники и личные сообщения коллег, относящиеся к встречам каспийского полоза в Казахстане. Для однообразия координаты всех встреч вида в подписях к рис. 1 приведены в формате «ГГ ММ.ммм'».

\section{РЕЗУЛЬТАТЫ И ИХ ОБСУЖДЕНИЕ}

Распространение. Рассмотрим, придерживаясь хронологического порядка, места находок вида, территориально относящихся (точно или предположительно) к современной Республики Казахстан. 
Вид описан И. И. Лепёхиным в «Дневных записках», датированных 9 - 18 августа 1769 г., на основании экземпляра, убитого в «Яицкой степи» по дороге вдоль северного берега Каспийского моря из Красного Яра (ныне - Россия, Астраханская область, Красноярский район, с. Красный Яр) в Гурьев городок (Казахстан, Атырауская область, г. Атырау). Надо заметить, что в то время Каспийское море было более обширным, чем сейчас, и, к примеру, Красный Яр находился почти на северном береге моря. Между современными Красноярским районом и Атырау отряд Лепёхина пересек нынешние Курмангазинский, Исатайский и Махамбетский районы Атырауской области Казахстана. «Страшный родъ змей в степи ночью заставляль насъ быть осторожными. Красноярцы ихъ Желтопузиками называютъ. Правда, оне боятся человека: но когда ихъ раздразнишь то съ великимъ свирептствомъ бросаются. Пресмыкаются всегда поднявъ голову въ верхъ съ лишком на аршинъ и про-ницательнымъ шипениемъ даютъ знать то место, где оне в кустарниках или поемныхъ лугах водятся. Мы небольшую изъ нихъ убили; но и та длиною была въ пять Парижских футовъ. Челюсти у нее вооружены двумя рядами острыхъ, однако мелких зубовъ. Изподъ весь даже до конца светложелтый. Спина и бока покрыты осьмнатцатью рядами чешуи, которой середина желтая, а кпая темныя; отъ чего произходятъ желтыя и темныя длинныя полосы попеременно» (Лепехин, 1771, с. 513 - 514). Описав вид, И. И. Лепёхин отнес таксон к линневскому роду Coluber, но не присвоил ему латинское название. Автором видового названия стал И. Ф. Гмелин (Gmelin, 1789), который предложил для этого вида, также включенного им в род Coluber, название caspius (p. 1112).

П. С. Палласу 9 мая 1793 г. в песчаной пустыне Салтан-Мурат (пески Батпайсагыр у границы Курмангазинского района Атырауской области Казахстана и Красноярского района Астраханской области России) встречались воинственные, но не-ядовитые змеи «Coluber Iaculator» (Pallas, 1799, S. 111 - 112; Паллас, 2008, с. 60). В палласовских записях 15 мая 1793 г. сообщается, что по дороге от колодцев Хонггора к Чапчачи в ровной степи появилось много крупных агрессивных змей (Pallas, 1799, S. 29; Паллас, 2008, с. 77). Последнее сообщение, скорее всего, также относится к каспийским полозам из Курмангазинского района.

И. В. Равинский (1809) при описании Астраханской губернии сообщает: «Из змей здесь водятся: самыя большия желтопузы на Уральской степи в горах Арзагарских» (с. 150). «Арзагарские горы» - это, вероятно, холмы в окрестностях с. Аз- гир (Курмангазинский район Атырауской области Казахстана).

П. С. Паллас (Pallas, [1814], p. 42 - 43) в типовую территорию вида Coluber trabalis (замещающее название для Coluber caspius Gmelin, 1789) включил частично относящиеся к современному Казахстану: «desertum Tataricum»- пустыни Центральной Азии, «Rhymnum»-p. Урал, «mare caspium»-Каспийское море.

И. А. Двигубский (1832) поясняет, что уж желтопуз Coluber trabalis водится «по степям отъ Днестра до Каспійскаго моря и далее <...>. Цвет на спине очень изменяется. Если полосы темныя съ желтыми на спине попеременны, то это Coluber Caspius, Lepechini» (c. 20).

И. Б. Ауэрбах в 1854 г. на горе Малое Богдо (Западно-Казахстанская область, Бокейординский район) добыл змею, которую К. Ф. Кесслер (1871) определил как «Zamenis Karelini'» (c. 73). Позже А. М. Никольский $(1905$, с. $228 ; 1916$, с. 82 - 83) приводит название Zamenis karelini, со ссылкой на эту публикацию Кесслера, в качестве одного из синонимов Zamenis gemonensis.

В середине XIX в. в Берлинском зоологическом музее хранился экземпляр каспийского полоза Zamenis trabalis (caspius) из азиатской России «asiat. Russland» (Lichtenstein, Martens, 1856, S. 29), возможно, с современной территории Казахстана. В источнике не приводится информация о более конкретном месте добычи, коллекторе и дате. Однако можно заметить, что в то время граница Европы и Азии чаще проводилась по Уральскому хребту и по р. Урал.

Г. С. Карелин (1883) во время экспедиции для осмотра северо-восточных берегов Каспийского моря в 1832 г. отметил каспийского полоза около Гурьева городка. М. Н. Богданов, редактор посмертного издания «Путешествия Г. С. Карелина по Каспийскому морю», пояснил: «Печатаем список животных и растений без изменений по рукописи. Но так как многие виды определены не точно, то считаем необходимым снабдить этот список поправками и примечаниями. Список пресмыкающихся < ..> обязательно просмотрел Ак. А. А. Штраух» (с. 116). В разделе «Пресмыкающияся», составленном Г. С. Карелиным, приведен вид «16. Coluber caspius. Желтопузик; большая змея, у Гурьева». «Поправки» списка рептилий, внесенные Штраухом, относились и к этому виду: «16. Zamenis trabalis» (c. 127).

Н. М. Кулагин (1888; цит. по: Никольский, 1916 , с. 83, 88) сообщал об экземпляре Zamenis trabalis из Киргизской степи Букеевской орды, хранящемся в Московском музее. 
А. М. Никольский $(1905,1907)$ в очерках «Zamenis gemonensis Laur.» писал: «Русская разновидность var. caspius Iwan. сверху сераго или светло-оливковаго цвета, каждая чешуйка съ желтоватой или светло-бурой полосой, брюхо одноцветное, оранжевое или красное. $<\ldots$.. > Въ Европейской Россіи этотъ полозъ водится въ южно-русскихъ степяхъ на северь до 50 с. ш. и отъ Бессарабіи до низовьевъ р. Урала» (1905, с. 229; 1907, с. 108-109).

И. В. Васильев (1914) изучал герпетофауну полуострова Мангышлак в 1906 г. Он писал о «Zamenis gemonensis var. caspius Iwan»: «Мне удалось добыть на полуострове два превосходных экземпляра этой крупной змеи в Кара-тау, у Джармыша $(7, \mathrm{~V})$, в ровной, глинистой, заросшей грубым, щетинистым злаком (Lasiagrostis splendens) долине» (c. 103). «Размеры добытых мною экземпляров: одного - 1524 миллим., другого - 1295 миллим., последний с крупными, черными пятнами вдоль спины» (с. 104). А. М. Никольский $(1916$, с. 85) сообщал только об одном экземпляре, добытом Васильевым на Мангышлаке и хранившемся в Петроградском зоологическом музее: «№ 10519 spr. Mangyschlack am m. Caspium, Wasiliew, 1906». Ныне полуостров Мангышлак находится в Тупкараганском районе Мангистауской области Казахстана.

А. М. Никольским (1916) выделено четыре цветовые формы вида Zamenis gemonensis. К форме, возможно, населяющей Казахстан, он отнес «Zamenis gemonensis caspius Iwan. Сверху сераго или оливково-сераго цвета, безъ пятенъ или съ черными пятнами, на каждой чешуйке желтоватая или светлобурая продольная полоска, брюхо оранжевое или красное безъ пятенъ. Водится въ юговост. Европе, юго-вост. России, на Кавказе на северъ от главнаго хребта» (с. 86).

Заметим, что автором названия caspius А. М. Никольский, как и И. В. Васильев, называет «Iwan». Ясно, что речь идет об Иване Ивановиче Лепёхине. Л. Ланц (Lantz, 1922, p. 194) обратил внимание на то, что часто авторство формы «Zamenis gemonensis caspius Gmelin» приписывают «Ивану» по ошибке вслед за авторами «Erpétologie générale» (Duméril et al., 1854), перепутав имя Ивана Лепёхина с его фамилией. Э. Чжао и К. Адлер (Zhao, Adler, 1993, p. 253), указывая на эту ошибку, ссылаются на более поздние публикации А. Гюнтера (Günter, 1858, p. 102) и Ж. А. Буланже (Boulenger, 1893, p. 395). В российскую литературу «Ивана» ввел, вероятно, А. М. Никольский (1899, с. 54 ; цит. по: Боркин, 2000 , с. 193). Но, как отмечалось выше, авторство названия caspius для данного вида принадлежит И. Ф. Гмелину (Gmelin, 1789). Некоторые подробности истории с «Иваном» можно найти в статье Л. Я. Боркина (2000).
Ю. М. Ралль (1935) с М. П. Демяшевым весной 1934 г. в степи Бесь-Чохо (возвышенность Бесшокы, Атырауская область, Курмангазинский район) поймали «желтопуза (Zamenis gemonensis)» «длиной 200 см» и «нашли еще два трупа молодых желтопузов» (с. 59 - 60). В статье описаны обстоятельства поимки крупного экземпляра: «Найдя подозрительные змеиные выползки, мы в продолжение нескольких дней осмотрели всю степь, когда, уже разочаровавшись в поисках, я увидел прекрасный экземпляр желтопуза. Крупная и сильная змея, заметив меня, неторопливо направилась в сторону, как бы плывя по низкорослому войлоку ибэлека, и была в это время так красива и непринужденна в своих движениях, что я невольно задержался с нападением. Во время поимки желтопуз смело бросался на нас, как разворачивающаяся пружина, и, немало помучив преследователей, чуть-было не скрылся в суслиной ноpe. Схваченный за хвост, он молниеносно выскочил наружу и бросился на нас с новой яростью» (Ралль, 1935, с. 60).

П. В. Терентьев и С. А. Чернов (1936) писали, что нахождение желтобрюха Coluber jugularis «на п-ове Мангышлак, нуждается в подтверждении» (с. 63). С. Г. Гребельский (1939), проводивший фаунистические и экологические наблюдения на Мангышлаке летом 1936 г., подтверждал обитание вида в горах Каратау: «Coluber jugularis caspius L. - желтобрюхий полоз встречен в КараТау. Васильевым отмечен тоже только в Кара-Тау, очевидно, распространение этого вида ограничено» (с. 218). П. В. Терентьев и С. А. Чернов (1949) предположили: «Указания на нахождение этого полоза $<\ldots>$ на полуострове Мангышлаке, вероятно, основаны на неправильном определении» (c. 240). В определителе Терентьева и Чернова (1949) на карте 29 (с. 318) северо-восточная граница распространения каспийского полоза, проходящая через Казахстан, проведена значительно севернее Ман-гышлака, почему-то по левобережью Нижнего Урала.

С. А. Чернов $(1954$, с. 149$)$ недоверчиво отнесся к находке Г. С. Карелиным (1883) вида у Гурьева, допуская, что Карелин мог ошибочно принять за желтобрюхого полоза Coluber jugularis другой вид змей - узорчатого полоза Elaphe dione. Черновым (1954) также с недоверием восприняты сведения Гребельского о встрече каспийского полоза в северной оконечности полуострова, поскольку «среди пресмыкающихся, собранных Гребельским во время поездки, указанного в его статье Coluber jugularis caspius Gmel. не оказалось; вместе с тем были обнаружены молодой четырехполосый полоз и стрела-змея, не отмечен- 
ные автором» (с. 149). В списках литературы двух упомянутых публикаций середины XX в. (Терентьев, Чернов, 1949; Чернов, 1954) присутствует статья С. Г. Гребельского (1939), но отсутствует статья И. В. Васильева (1914).

К. П. Параскив (1956) ни разу не вспомнил публикацию Г. С. Карелина (1883) с информацией о каспийском полозе у Гурьева, а также проигнорировал опубликованные сведения о каспийском полозе на Мангышлаке, хотя статьи Васильева и Гребельского были внесены им в список литературы. К. П. Параскивом о распространении вида на территории Казахстана в очерке «Желтобрюхий полоз или желтобрюх. Coluber jugularis (Linnaeus, 1758)» сообщается: «В низовьях правобережья р. Урала найден Лепехиным (1795), в районе древней степи Бесь-Чохо, в Волжско-Уральских песках - Раллем (1935)» (с. 153). На карте 57 «Распространение желтобрюхого полоза Coluber jugularis Linnaeus в Казахстане» (Параскив, 1956, c. 154) отмечена единственная точка, обозначенная как «Литературные данные» и явно относящаяся к публикации Ю. М. Ралля.

К. П. Параскив и П. М. Бутовский (1960) считали местность Бесшокы единственным достоверным пунктом обитания вида на территории Западного Казахстана. «Желтобрюхий полоз (Соluber jugularis L., 1758). Единственная достоверная находка этой змеи в Западном Казахстане принадлежит Ю. М. Раллю (1935). Полоз был найден в полынно-эбелековой степи, в местности Бес-Чохо. Западнее, в районе Богдинских полезащитных полос, он уже не редок (Чернов, 1954)» (с. 157).

В справочнике-определителе А. Г. Банникова с соавторами (1971) ареал желтобрюхого полоза «Coluber jugularis (L.)» (c. 216) на карте 89 (с. 217) не заходит в Мангышлак, а восточная граница распространения в Казахстане проходит по Левобережью Урала. В определителе А. Г. Банникова и соавторов (1977) ареал желтобрюхого полоза «Соluber jugularis (L., 1758)» (с. 264) на карте 108 (c. 379) также не захватывает Мангышлак, а восточная граница распространения в Казахстане проходит по междуречью Волги и Урала, не заходя в Уральский бассейн. Авторы определителя сообщают: «Европейскую часть ареала, а также северную половину Турции занимает подвид $C$. j. caspius Gmelin, 1789, характеризующийся оливковосерой, палево-бурой или желтовато-оливковой окраской верхней стороны тела со светлой продольной полоской на каждой чешуйке, желтой радужной оболочкой глаз и желтоватым брюхом» (c. 264-265).

В. В. Неручев и Н. Ф. Васильев (1978), изучавшие в 1962 - 1976 гг. фауну рептилий Северо-
Восточного Прикаспия, не обнаружили здесь желтобрюхого полоза. Однако, позже, по результатам исследований герпетофауны речных долин Северного Прикаспия, в 1976 - 1987 гг, В.В. Неручев с соавторами (1990) отмечают данный вид в долине Волги и Волго-Уральском междуречье.

В учебном пособии Л. А. Байдуловой с соавторами (2001) указывается, что этот полоз «в Волжско-Уральском междуречье достигает северо-восточных пределов своего распространения, но точная граница не установлена». В Западно-Казахстанской области он «встречается в Бокей-Ординском и Жангалинском районах» (с. 75) и является здесь неизученным видом. Более конкретная информация о встречах каспийского полоза в этих районах в публикации отсутствует.

Н. Б. Ананьева с соавторами (2004), описывая распространение вида, сообщают: «На востоке каспийский полоз проникает в Азию - в ВолгоУральском междуречье (западный Казахстан)» (c. 156). Подобную информацию приводят Б. С. Туниев с соавторами $(2009$, с. 60). С. Л. Кузьмин и Д. В. Семенов (2006) указывают на распространение желтобрюхого полоза Coluber caspius Gmelin, 1789 в районах Казахстана, граничащих с югом европейской части России (с. 69).

Начиная с 2010 г. выходит ряд работ, в которых отмечается обитание каспийского полоза как в некоторых отмеченных выше, так и в других пунктах Западного Казахстана. В последнем издании Красной книги Республики Казахстан указывается единственное местонахождение вида для Казахстана - «в реликтовой степи Бес-Чохо Волго-Уральского междуречья» (Брушко, Зима, 2010, с. 78) со ссылкой на статью Ю. М. Ралля (1935).

В третьем томе «Национального атласа Республики Казахстан» распространение вида «Желтобрюхий или каспийский полоз Hierophis caspius» отмечено на карте одной жирной точкой на территории Курмангазинского района Атырауской области, севернее пос. Ганюшкино, между $47^{\circ}$ и $48^{\circ}$ с. ш., $49^{\circ}$ и $50^{\circ}$ в. д. (Распространение амфибий..., 2010).

Т. Н. Дуйсебаева с соавторами (2010) пишут, что по устному сообщению Ф. Г. Бидашко им зарегистрирован каспийский полоз «в двух точках: в окрестностях пос. Индерборское 29 июня 1998 г. и в окрестностях горы Малое Богдо 21 апреля 2004 г.» (с. 94). Можно заметить, что гора Малое Богдо находится в Бокейординском районе Западно-Казахстанской области, а правильное название административного центра Индерского района Атырауской области - пос. Индерборский. Ф. А. Сараев и М. В. Пестов (2010, с. 184) дополняют и уточняют информацию о встречах каспий- 


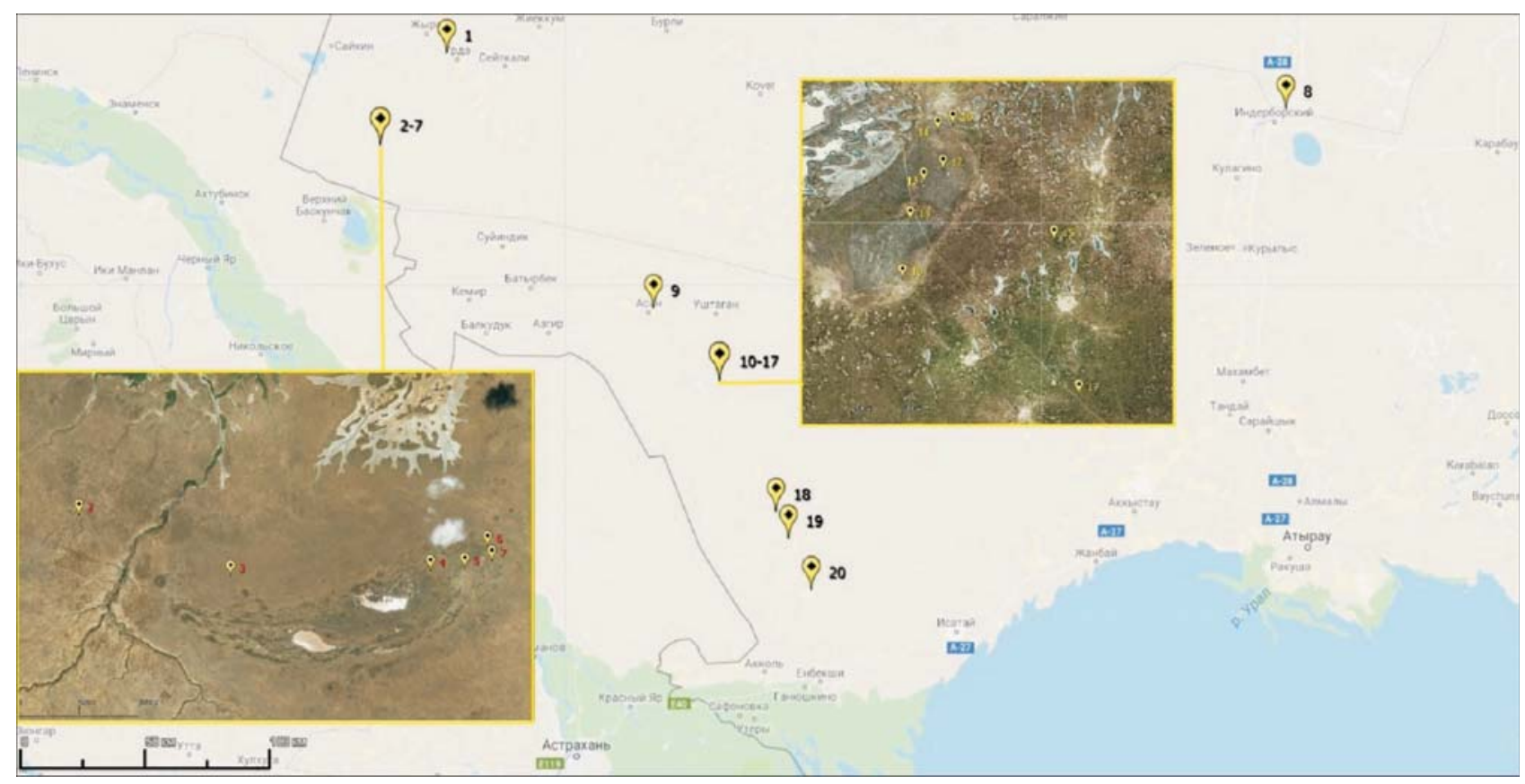

Рис. 1. Места встреч каспийского полоза в Казахстане в 1998 - 2018 гг.: 1 - Западно-Казахстанская область, Бокейординский район, окрестности с. Хан Ордасы, кладбище Бабай-сад, 4847.305' N и 47²2.559' E, 13 - 14 июня 2018 г. - Ахмеденов и др., 2018 c, с. 89; наши данные; 2 - Западно-Казахстанская область, Бокейординский район, на грунтовой дороге между горой Малое Богдо и с. Сайхин, 48²8.392' N и 4701.497' Е, 30 апреля 2018 г. - Ахмеденов и др., 2018 a , с. 288, 289; 3 - Западно-Казахстанская область, Бокейординский район, гора Малое Богдо, 48²8.000' N и 4703.000' Е, 21 апреля 2004 г. и 15 июня 2008 г. - Дуйсебаева и др., 2010, с. 94; Сараев, Пестов, 2010, с. 184; 4 Западно-Казахстанская область, Бокейординский район, прилегающая к юго-западному склону горы Малое Богдо равнина, 48²8.035' N и 4704.986' Е, 25 мая 2017 г. - Ахмеденов и др., 2017 a, с. 137; 5 - Западно-Казахстанская область, Бокейординский район, гора Малое Богдо, 48²8.048' N и 4705.326' Е, 23 мая 2012 г. - Боркин и др., 2014, c. 213; Боркин, Литвинчук, 2015, с. 71; 6 - Западно-Казахстанская область, Бокейординский район, на вершине горы Малое Богдо, в расщелине, 48²8.188' N и 4705.548' Е, 29 апреля 2018 г. - Ахмеденов и др., 2018 a, с. 288,289 ; наши данные; 7 - Западно-Казахстанская область, Бокейординский район, восточное подножие горы Малое Богдо, 48 28.098' N и 4705.591' Е, 25 мая 2017 г. - Ахмеденов и др., 2017 a, с. 137; 8 - Западно-Казахстанская область, Акжаикский район, севернее пос. Индерборский, 48³6.000' N и 51²9.000' Е, 29 июня1998 г. - Дуйсебаева и др., 2010, с. 94; Сараев, Пестов, 2010, с. 184; 9 - Атырауская область, Курмангазинский район, окрестности с. Асан, $47^{\circ} 55.000^{\prime} \mathrm{N}$ и $48^{\circ} 28.000^{\prime}$ Е, 5 мая 2009 г. - Сараев, Пестов, 2010, с. 184; 10 - Атырауская область, Курмангазинский район, возвышенность Бес-Чохо, 47²0.000' N и 4849.000' Е, 2 мая 2009 г. - Островских и др., 2010, с. 253; Сараев, Пестов, 2010, с. 184; 11 - Атырауская область, Курмангазинский район, возвышенность Бес-Чохо, 47³9.832' N и 4848.398' Е, 23 мая 2017 г. - наши данные; 12 - Атырауская область, Курмангазинский район, возвышенность БесЧохо, 47³8.832' N и 4848.61' E, 23 мая 2017 г. - наши данные; 13 - Атырауская область, Курмангазинский район, возвышенность Бес-Чохо, 47³8.499' N и 4847.837’ Е, 22 мая 2017 г. - наши данные; 14 - Атырауская область, Курмангазинский район, возвышенность Бес-Чохо, 47³7.498' N и 48²7.304' Е, 24 мая 2017 г. - наши данные; 15 Атырауская область, Курмангазинский район, окрестности кладбища Шадьямола, 47³7.000' N и 4853.000' Е, 7 мая 2009 г. - Островских и др., 2010, с. 253; Сараев, Пестов, 2010, с. 184; 16 - Атырауская область, Курмангазинский район, южная часть Бес-Чохо, 47³6.000' N и 4847.000' Е, 8 мая 2009 г. - Островских и др., 2010, с. 253; Сараев, Пестов, 2010, с. 184; 17 - Атырауская область, Курмангазинский район, 5 км южнее кладбища Шадьямола, 47³3.000' N и 4854.000' Е, 1 мая 2009 г. - Островских и др., 2010, с. 253; Сараев, Пестов, 2010 , с. $184 ; 18$ Атырауская область, Курмангазинский район, 66 км севернее пос. Ганюшкино, грунтовая дорога, 47² $12.865^{\prime} \mathrm{N}$ и 4906.881' Е, 22 мая 2017 г. - наши данные; 19 - Атырауская область, Курмангазинский район, 57 км севернее пос. Ганюшкино, грунтовая дорога, 4707.134' N и 49¹0.836' Е, 22 мая 2017 г. - наши данные; 20 - Атырауская область, Курмангазинский район, 37 км севернее пос. Ганюшкино, грунтовая дорога, 4656.536' N и $49^{\circ} 18.177^{\prime} \mathrm{E}$, 22 мая 2017 г. - наши данные

Fig. 1. Meeting places of Hierophis caspius in Kazakhstan in 1998-2018: 1 - West Kazakhstan region, Bokeyordinsky district, surroundings with. Khan Ordasy, Babai-Sad cemetery, 48 47.305' N and 47²2.559' E, June 13-14, 2018 Akhmedenov et al., 2018 c, p. 89; our data; 2 - West Kazakhstan region, Bokeyordinsky district, on a dirt road between the

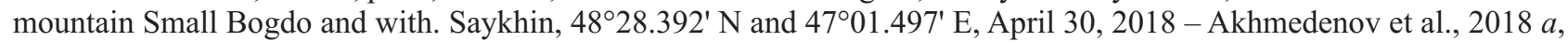

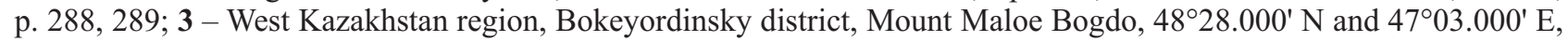
April 21, 2004 and June 15, 2008 - Duisebaeva et al., 2010, p. 94; Saraev, Pestov, 2010, p. 184; 4 - 
ского полоза тем же исследователем - В. Г. Бидашко - в тех же пунктах (рис. 1, пункты 3 и 8), приводя их приблизительные координаты: «Западно-Казахстанская область, гора Малое Богдо (48²8 N; $47^{\circ} 03$ E), 21.04.2004 и 15.06.2008 (Бидашко, устн. сообщ.)» и «севернее пос. Индерборский $\left(48^{\circ} 36 \mathrm{~N}\right.$; 5149 Е), 29.06.1998 (Бидашко, устн. сообщ.)» (с. 184). Отметим, что обитание вида в северных окрестностях пос. Индерборский, при границе Акжаикского района Западно-Казахстанской области и Индерского района Атырауской области, пока не подтверждено другими исследователями. Так, здесь в июне 2018 г. нам не удалось встретить ни каспийских полозов, ни следов их обитания.

В ходе проведения герпетологических исследований в Западном Казахстане (Курмангазинский район Атырауской области) в период $1-9$ мая 2009 г. каспийский полоз обнаружен С. В. Островских с соавторами (2010), как на территории возвышенности Бесшокы (18 половозрелых и две ювенильных особи, а также 16 выползков разновозрастных животных), так и на расстоянии более чем 30 км от ее границ. В уже упомянутой публикации (Сараев, Пестов, 2010, с. 184) конкретизируются координаты и этих мест находок вида (рис. 1, пункты 9, 10, 15-17).

Монография П. В. Дебело и А. А. Чибилёва (2013) содержит указания на четыре местонахождения каспийского полоза Hierophis caspius в быв- шей Гурьевской области (с. 260) со ссылками на публикации Ралля (1935), Островских с соавторами (2010), Сараева и Пестова (2010). Также в этой монографии, как выяснилось, к каспийскому полозу относится информация о ящеричной змее Malpolon monspessulanus, которая якобы наблюдалась А. А. Чибилёвым «на горе М. Богдо (Жамантау) в Бокейординском районе Западно-Казахстанской области (2000, 2011 г.)» (с. 262). Позже установлено (академик РАН Александр Александрович Чибилёв, личное сообщение, 2017), что здесь за ящеричных змей ошибочно были приняты молодые каспийские полозы.

Е. А. Дунаев и В. Ф. Орлова безосновательно сообщили о распространении вида «до Восточного Казахстана» (2014, с. 61; 2017, с. 262). К сожалению, ошибка про Восточный Казахстан стала тиражироваться в интернете.

На Малом Богдо (рис. 1, пункт 5) 23 мая 2012 г. членами российско-казахстанской комплексной научной экспедиции отмечены четыре взрослых особи каспийского полоза, а также линные выползки и сухие части тела змей данного вида (Боркин и др., 2014; Боркин, Литвинчук, 2015). М. А. Чирикова и В. Л. Казенас (2015) написали, не используя новые опубликованные данные о распространении желтобрюхого полоза Hierophis caspius в Казахстане, что «единственная находка известна из местности Бес-Чохо (западная

West Kazakhstan region, Bokeyordinsky district adjacent to the southwestern slope of the Maloe Bogdo plain, $48^{\circ} 28.035^{\prime} \mathrm{N}$ and 47 04.986' E, May 25, 2017 - Akhmedenov et al., 2017 a, p. 137; 5 - West Kazakhstan region, Bokeyordinsky district, Mount Maloe Bogdo, 48²8.048' N and 4705.326' E, May 23, 2012 - Borkin et al., 2014, p. 213; Borkin, Litvinchuk, 2015 , p. $71 ; 6$ - West Kazakhstan region, Bokeyordinsky district, on the peak of Mount Maloe Bogdo, in a crevice, $48^{\circ} 28.188^{\prime} \mathrm{N}$ and 47 05.548' E, April 29, 2018 - Akhmedenov et al., 2018 a, p. 288, 289; our data; 7 - West Kazakhstan region, Bokeyordinsky district, the eastern foot of the Maloe Bogdo mountain, 48 28.098' N and 47 05.591'E, May 25, $2017-$ Akhmedenov et al., 2017 a, p. 137; 8 - West Kazakhstan region, Akzhaiksky district, north of the village. Inderborsk, 48 36.000' N and 51 $49.000^{\prime}$ E, June 29, 1998 - Duisebaeva et al., 2010, p. 94; Saraev, Pestov, 2010, p. 184; 9 - Atyrau region, Kurmangazinsky district, surroundings with. Asan, 4755.000' N and 48²8.000' E, May 5, 2009 - Saraev, Pestov, 2010, p. 184; 10 - Atyrau Region, Kurmangazinsky District, Bes-Chokho Upland, 47 40.000' N and 4849.000' E, May 2, 2009 - Ostrovsky et al., 2010, p. 253; Saraev, Pestov, 2010, p. 184; 11 - Atyrau region, Kurmangazinsky district, BesChokho hill, 47 $39.832^{\prime} \mathrm{N}$ and $48^{\circ} 48.398^{\prime} \mathrm{E}$, May 23, 2017 - our data; 12 - Atyrau region, Kurmangazinsky district, Bes-

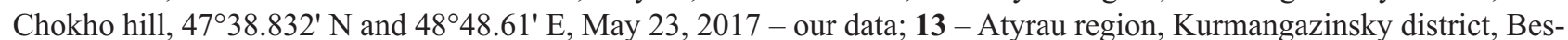
Chokho hill, 47 $38.499^{\prime} \mathrm{N}$ and $48^{\circ}$ 47.837' E, May 22, 2017 - our data; 14 - Atyrau region, Kurmangazinsky district, BesChokho hill, 47 $37.498^{\prime} \mathrm{N}$ and 48 47.304' E, May 24, 2017 - our data; 15 -Atyrau region, Kurmangazinsky district, vicinity of the Shadyamola cemetery, 47³7.000' N and 48 $53.000^{\prime}$ E, May 7, 2009 - Ostrovsky et al., 2010, p. 253; Saraev, Pestov, 2010, p. 184; 16 - Atyrau region, Kurmangazinsky district, southern part of Bes-Chokho, 47³6.000' N and 48 47.000' E, May 8, 2009 - Ostrovsky et al., 2010, p. 253; Saraev, Pestov, 2010, p. 184; 17 - Atyrau region, Kurmangazinsky district, 5

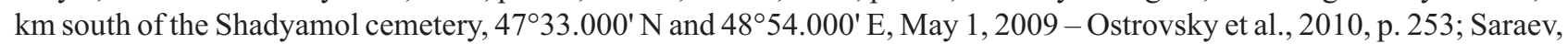
Pestov, 2010, p. 184; 18 - Atyrau region, Kurmangazinsky district, 66 km north of the village. Ganyushkino, dirt road, $47^{\circ} 12.865^{\prime} \mathrm{N}$ and $49^{\circ} 06.881^{\prime} \mathrm{E}$, May 22, 2017 - our data; 19 -Atyrau region, Kurmangazinsky district, $57 \mathrm{~km}$ north of the village. Ganyushkino, dirt road, $47^{\circ} 07.134^{\prime} \mathrm{N}$ and $49^{\circ} 10.836^{\prime} \mathrm{E}$, May 22, 2017 - our data; 20 - Atyrau region, Kurmangazinsky district, $37 \mathrm{~km}$ north of the village. Ganyushkino, dirt road, $46^{\circ} 56.536^{\prime} \mathrm{N}$ and $49^{\circ} 18.177^{\prime} \mathrm{E}$, May 22 , 2017 - our data 
часть Атырауской области). Местом обитания является эбелеково-полынная степь с редкими кустами» (с. 111).

В Курмангазинском районе Атырауской области на грунтовой дороге, ведущей из пос. Ганюшкино к возвышенности Бес-Чохо, мы подобрали 22 мая 2017 г. трех раздавленных автотранспортом каспийских полозов (рис. 1, пункты 18 - 20; рис. 2). В этот же день, на самой возвышенности Бес-Чохо, нами найден выползок каспийского полоза (рис. 1, пункт 13); 23 мая встречены две змеи данного вида (рис. 1, пункты 11 и 12); 24 мая-еще одна змея (рис. 1, пункт 14).

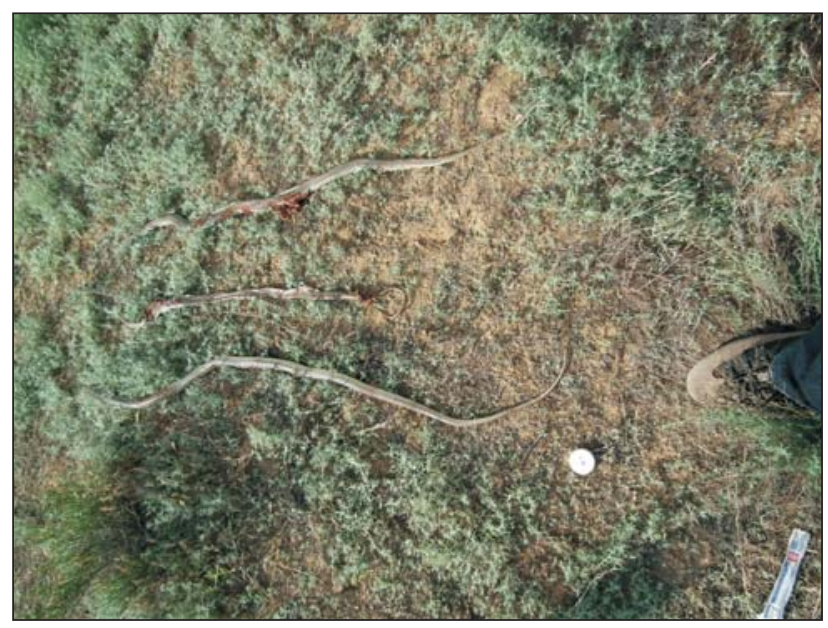

Рис. 2. Три экземпляра каспийского полоза, погибшие под колесами автотранспорта на грунтовой дороге между пос. Ганюшкино и возвышенностью Бес-Чохо (Курмангазинский район Атырауской области Казахстана, 22 мая 2017 г.)

Fig. 2. Three specimens of Hierophis caspius, killed under the wheels of vehicles on a dirt road between the Ganyushkino village and the Bes-Chokho hill (Kurmangazinsky district of the Atyrau region of Kazakhstan, 22 May, 2017)

В Бокейординском районе Западно-Казахстанской области 25 мая 2017 г. один каспийский полоз пойман нами у восточного подножия Малое Богдо (рис. 1, пункт 7), другой - на равнине, прилегающей к юго-западному склону этой горы (рис. 2, пункт 4) (Ахмеденов и др., $2017 a$, с. 137, 2017 b, c. $116,2018 a$, c. 288,2018 b, c. 20,2018 c, c. 91$)$.

Нашими исследованиями 2018 г. было подтверждено обитание каспийского полоза не только на горе Малое Богдо, но и в ее северо-западных окрестностях (рис. 1, пункты 6 и 2 соответственно). Половозрелый экземпляр отловлен на вершине горы Малое Богдо в расщелине 29 апреля 2018 г. На грунтовой дороге от горы Малое Богдо в с. Сайхин 30 апреля была найдена ювенильная особь, раздавленная автотранспортом (Ахмеденов и др., 2018 a, c. $288,289,2018$ b, c. 20$)$.
Состояние и перспективы охраны. В Бокейординском районе Западно-Казахстанской области, в окрестностях с. Хан Ордасы (рис. 1, пункт 1), 13 и 14 июня 2018 г. членами международной научно-познавательной экспедиции наблюдался взрослый экземпляр каспийского полоза и был найден линный выползок крупной змеи данного вида (Ахмеденов и др., 2018 c, с. 89).

Выяснилось, что в Урдинском госучреждении по охране лесов и животного мира хранится «Предварительный список наземных позвоночных обитающих в Урдинском районе Уральской области КазССР», составленный в 1988 - 1989 гг. кандидатом биологических наук, старшим преподавателем Пензенского педагогического института Владимиром Юрьевичем Ильиным (ныне доктор биологических наук, профессор, работает в Пензенском государственном университете). В списке В. Ю. Ильин отметил желтобрюхого полоза в качестве очень редкого вида глинистой полупустыни. Однако по личному сообщению В. Ю. Ильина (2019), им данный вид никогда не наблюдался в Бокейординском районе и был включен в список в качестве возможно обитающего здесь.

В паспорте Государственного природного заказника местного значения «Орда» в качестве индикаторного вида, определяющего состояние животного мира, отмечен «Полоз» - без указания видовой принадлежности - с оптимальной численностью 3 экз./га и фактической численностью 7 экз./га (Паспорт государственного..., 2012, с. 4). В то же время в этом документе среди редких и исчезающих видов животных каспийский полоз не указан.

Таким образом, в Казахстане, по последним данным, каспийский полоз достоверно обитает и, следовательно, охраняется лишь на единственной особо охраняемой природной территории (ООПТ) республики - в Государственном природном заказнике местного значения «Орда», где обнаружен нами в июне 2018 г. В заповедниках Казахстана (Рустамов, Щербак, 1987) и на других ООПТ республики, включая Государственный природный заказник местного значения «Орда» (Петренко и др., 1998), вид ранее не был отмечен.

Для сохранения вида в Республике Казахстан важной территорией является гора Малое Богдо с ее окрестностями, где отмечается относительно высокое обилие вида. Вблизи этой горы расположено месторождение полезных ископаемых «Жаман-Тау». На месторождении выявлены перспективные участки с запасами песчаника, гипса, известняка и валунно-галечные (щебеночные) отложения, пригодные для строительных ра- 
бот в ориентировочном объеме 2.7 млн м ${ }^{3}$. Начинается их освоение. Гору Малое Богдо раньше арендовали российские военные, сейчас они ее покинули. На горе Малое Богдо планируется добывать бутовый камень. В Прикаспийской низменности ландшафты Малобогдинского солянокупольного района являются одной из ключевых ландшафтных и биологических территорий. Очень актуальным стало обоснование создания ООПТ «Гора Малое Богдо». Такая ООПТ будет способствовать сохранению не только карстовых форм рельефа территории, но и редких видов растений и животных, в частности каспийского полоза (Ахмеденов и др., $2017 a, 2018 b$ ).

Согласно последним достоверным данным, каспийский полоз - единственный вид офидиофауны Западного Казахстана, занесенный в Красную книгу Республики Казахстан (2010). Другие виды змей из республиканской Красной книги Западный Казахстан достоверно не населяют.

\section{ВЫВОДЫ}

1. Каспийский полоз в настоящее время, по достоверным данным, населяет в Казахстане Волго-Уральское междуречье от с. Хан Ордасы Бокейординского района Западно-Казахстанской области (на севере) до северных окрестностей пос. Ганюшкино Курмангазинского района Атырауской области (на юге). Ранее опубликованные сведения об обитании вида в окрестностях г. Атырау, в Жангалинском районе Западно-Казахстанской области, а также за пределами Волго-Уральского междуречья - на Мангышлаке (Тупкараганский район Мангистауской области) и в северных окрестностях пос. Индерборский (Акжаикский район Западно-Казахстанской области и Индерский район Атырауской области) - требуют подтверждения. Информация о распространении в Восточном Казахстане является ошибочной.

2. Вид, согласно последним данным, достоверно обитает сейчас лишь на одной из ООПТ Казахстана - государственном природном заказнике местного значения «Орда» (Бокейординский район Западно-Казахстанской области).

3. Для сохранения вида в Казахстане перспективно обоснование и создание ООПТ «Гора Малое Богдо» в Бокейординском районе ЗападноКазахстанской области.

\section{Благодарности}

Авторы выражают признательность Е. Б. Ахметову, О. Г. Калмыковой и М. И. Шпигельману за помощь при сборе полевого материала; А. А. Чибилёву и В. Ю. Ильину за консультации.

\section{СПИСОК ЛИТЕРАТУРЫ}

Ананьева Н. Б., Орлов Н. Л., Халиков Р. Г., Даревский И. С., Рябов С. А., Барабанов А. В. 2004. Атлас пресмыкающихся Северной Евразии (таксономическое разнообразие, распространение и природоохранный статус) / Зоол. ин-т РАН. СПб. 232 с.

Ахмеденов К. М., Бакиев А. Г., Горелов Р. А., Калмыкова О. Г. 2017 а. К герпетофауне района горы Малое Богдо // Изв. Самар. науч. центра РАН. Т. 19, № 5. C. $13-139$.

Ахмеденов К. М., Бакиев А. Г., Горелов Р. А., Калмыкова О. Г., Клёнина А. А. 2017 б. Герпетофауна гор Большое и Малое Богдо, их окрестностей : история изучения, современный состав и перспективы сохранения // Охрана природы и региональное развитие : гармония и конфликты (к Году экологии в России) : материалы междунар. науч.-практ. конф. и шк.-семинара молодых ученых-степеведов «Геоэкологические проблемы степных регионов», проведенных в рамках XXI сессии Объединенного научного совета по фундаментальным географическим проблемам при Междунар. ассоциации академий наук (МААН) и Научного совета РАН по фундаментальным географическим проблемам. Оренбург : Ин-т степи УрО РАН. Т. І. С. 113 - 117.

Ахмеденов К. М., Абуова Р. С., Назарова Г. А. $2018 a$. Дополнения к герпетофауне горы Малое Богдо и его окрестностей // Вестн. Зап.-Казахст. гос. ун-та. № 3. С. $285-296$.

Ахмеденов К. М., Бакиев А. Г., Горелов Р. А., Калмыкова О. Г., Шпигельман М. И., Абуова Р. С. 2018 б. Материалы к созданию особо охраняемой природной территории «Гора Малое Богдо» в Западном Казахстане // Астрах. вестн. экол. образования. № 5. С. 18 - 26.

Ахмеденов К. М., Бакиев А. Г., Ефимов В. М., Кузовенко А. Е., Хайдаров Е. Е., Шпигельман М. И. 2018 в. Индер - перспективный геопарк Приуралья : Дневник международной научно-познавательной экспедиции в рамках программы «Рухани жаңғыру» и 55-летия Западно-Казахстанского аграрно-технического университета имени Жангир хана. Уральск : Зап.-Казахст. агр.-техн. ун-т им. Жангир хана. 118 с.

Байдулова Л., Булатова К., Карагойшин Ж. 2001. Животный мир Западно-Казахстанской области : учеб. пособие для учащихся общеобразовательных школ ЗКО. Уральск. $124 \mathrm{c.}$

Банников А. Г., Даревский И. С., Рустамов А. К. 1971. Земноводные и пресмыкающиеся СССР. М. : Мысль. 303 с.

Банников А. Г., Даревский И. С., Ищенко В. Г., Рустамов А. К., Щербак Н. Н. 1977. Определитель земноводных и пресмыкающихся фауны СССР. М. : Просвещение. 416 с.

Боркин Л. Я. 2000. Кто такой Iwan' (курьезный случай из истории герпетологии) // Русско-немецкие связи в биологии и медицине : опыт 300-летнего взаимодействия. СПб. : Санкт-Петербургский союз ученых. C. $191-200$.

Боркин Л. Я., Ганнибал Б. К., Голубев А. В. 2014. Дорогами Петра Симона Палласа (по западу Казахстана). СПб. ; Уральск : Евразийский союз учёных. 312 с. 


\section{РАСПРОСТРАНЕНИЕ, СОСТОЯНИЕ И ПЕРСПЕКТИВЫ ОХРАНЫ КАСПИЙСКОГО ПОЛОЗА}

Боркин Л. Я., Литвинчук С. Н. 2015. Герпетологические исследования на западе Казахстана : П. С. Паллас и современность // Природа западного Казахстана и Пётр Симон Паллас (полевые исследования 2012 года). СПб. : Европейский Дом. С. 53 - 79.

Брушко 3. К., Зима Ю. А. 2010. Сарыкурсак абжылан. Желтобрюхий полоз Coluber caspius Gmelin, 1779 // Красная книга Республики Казахстан. Изд. 4-е. Т. 1. Животные, ч. 1 : Позвоночные. Алматы. C. $78-79$.

Васильев И. 1914. К познанию фауны и биологии рептилий Мангишлака // Любитель природы. Т. 9, № 4. С. $97-107$.

Гребельский С. Г. 1939. Фаунистические и экологические наблюдения в стациях пустынь полуострова Мангышлак по материалам экспедиции 1936 г. // Тр. Военно-Медицинской академии РККА им. С. М. Кирова. Т. XVIII. С. $199-227$.

Двигубский И. 1832. Опыт естественной истории всех животных Российской Империи. [Т. 4]. Гады, или животные пресмыкающиеся. М. : Университетская Типография. 48 с.

Дебело П. В., Чибилёв А. А. 2013. Амфибии и рептилии Урало-Каспийского региона. Екатеринбург : РИО УрО РАН. Т. III. 400 с. (Сер. Природное разнообразие Урало-Каспийского региона).

Дуйсебаева Т. Н., Чирикова М. А., Зима Ю. А., Белялов О. В., Коваленко А. В. 2010. Новые данные о распространении амфибий и рептилий в Казахстане: обзор по первому десятилетию XXI века // Герпетологические исследования в Казахстане и сопредельных странах : сб. науч. статей. Аламаты : АСБК СОПК. С. $84-99$.

Дунаев Е.А., Орлова В.Ф. 2014. Змеи. Виды фауны России. Атлас-определитель. М. : Фитон XXI. $120 \mathrm{c}$.

Дунаев Е.А., Орлова В.Ф. 2017. Земноводные и пресмыкающиеся России. Атлас-определитель. Изд. 2-е, перераб. и доп. М. : Фитон XXI. 328 с.

Карелин Г. С. 1883. Путешествия Г. С. Карелина по Каспийскому морю // Зап. Императ. Рус. Геогр. О-ва. Т. 10. VI+497 с. ; 6 л. карт.

Кесслер К. Ф. 1871. Заметки о ящерицах и змеях, собранных И. Б. Ауэрбахом на горе Большой Богдо, во время путешествия 1854 года, составлена К. Ф. Кесслером в Киеве, в 1858 году // Зап. Императ. Рус. Геогр. О-ва по общей географии. T. IV. 69 - 75.

Красная книга Республики Казахстан. 2010. Изд. 4-е. Т. 1. Животные, ч. 1: Позвоночные. Алматы. $324 \mathrm{c}$.

Кузьмин С. Л., Семенов Д. В. 2006. Конспект фауны земноводных и пресмыкающихся России. М. : Т-во науч. изд. КМК. 139 с.

Лепёхин И. И. 1771. Дневные записки путешествия доктора и Академии Наук адъюнкта Ивана Лепехина по разным провинциям Российского государства, 1768 и 1769 году. [Ч. 1]. СПб. [VIII]+538 с.
Неручев В. В., Арженкова Н. Г., Шатилович О. А. 1990. Герпетофауна речных долин северного Прикаспия // Наземные и водные экосистемы. Горький : Издво Горьк. гос. ун-та. С. $26-33$.

Неручев В. В., Васильев Н. Ф. 1978. Фауна рептилий (Reptilia) Северо-Восточного Прикаспия // Вестн. зоологии. № 6. С. $36-41$.

Никольский А. М. 1905. Пресмыкающиеся и земноводные Российской империи. (Herpetologia rossica) // Зап. Императ. Акад. Наук. VIII cер. Физ.матем. отд. Т. XVII, № 1. СПб. 518 с.

Никольский А. М. 1907. Определитель пресмыкающихся и земноводных Российской Империи. Харьков : Русская Типография и Литография. 182 с.

Никольский А. М. 1916. Фауна России и сопредельных стран. Пресмыкающиеся (Reptilia). T. 2. Ophidia. Пг. : Типография Императ. Академии Наук. $350 \mathrm{c}$.

Островских С. В., Пестов М. В., Шапошников A. B. 2010. К вопросу о распространении каспийского полоза, Hierophis caspius (Gmelin, 1789), в Волго-Уральском междуречье // Герпетологические исследования в Казахстане и сопредельных странах. Алматы : АСБК - СОПК. С. 252 - 254.

Паллас П. С. 2008. Заметки о путешествии в южные наместничества Российской Империи в 1793 и 1794 годах. Том первый (избранное) / пер. с нем. Астрахань : Издат.-полигр. комплекс «Волга». 304 с.

Параскив К. П. 1956. Пресмыкающиеся Казахстана. Алма-Ата : Изд-во АН КазССР. 228 с.

Параскив К. П., Бутовский П. М. 1960. О фауне земноводных и пресмыкающихся Западного Казахстана // Тр. Ин-та зоол. АН КазССР. Т. 13. С. $148-159$.

Паспорт государственного природного заказника местного значения «ОРДА». 2012. Утвержден приказом Управления природных ресурсов и регулирования природопользования Западно-Казахстанской области от 25 ноября 2010 года № 86. Уральск. 7 с.

Петренко А. 3., Джубанов А. А., Фартушина М. М., Иркалиева Р. М., Дарбаева Т. Е., Кольченко О. Т., Чернышиов Д. М. 1998. Природно-ресурсный потенциал и проектируемые объекты заповедного фонда Западно-Казахстанской области. Уральск : Зап.-Казахст. гос. ун-т. 176 с.

Равинский И. В. 1809. Хозяйственное описание Астраханской и Кавказской Губерний. СПб. : Императорская Типография. [2]+VI+528+XIV с.

Ралль Ю. М. 1935. Древняя степь «БесьЧохо» в Волжско-Уральских песках // Природа. № 4. C. $55-60$.

Распространение амфибий и рептилий, занесенных в Красную книгу Казахстана и редких видов рыб. 2010. Масштаб 1:7500000 // Национальный атлас Республики Казахстан. Т. 3. Окружающая среда и экология. Алматы : Ин-т географии. С. 140.

Рустамов А. К., Щербак. Н. Н. 1987. Охрана амфибий и рептилий в заповедниках Средней Азии и 
Казахстана // Амфибии и рептилии заповедных территорий / ЦНИЛ Главохоты РСФСР. М. С. $101-118$.

Сараев Ф. А., Пестов М. В. 2010. К кадастру рептилий Северного и Северо-Восточного Прикаспия // Герпетологические исследования в Казахстане и сопредельных странах. Аламаты : АСБК - СОПК. С. 174- 193.

Терентьев П. В., Чернов С. А. 1936. Краткий определитель земноводных и пресмыкающихся СССР. М. ; Л. : Учпедгиз. 96 с.

Терентьев П. В., Чернов С. А. 1949. Определитель земноводных и пресмыкающихся. М. : Сов. наука. 340 с.

Туниев Б. С., Орлов Н. Л., Ананьева Н. Б., Агасян А. Л. 2009. Змеи Кавказа : таксономическое разнообразие, распространение, охрана. СПб.; М. : Т-во науч. изд. КМК. 223 с.

Чернов С. А. 1954. Эколого-фаунистический обзор пресмыкающихся юга междуречья Волга Урал // Тр. Зоол. ин-та АН СССР. Т. XVI. С. 137 - 158.

Чирикова М. А., Казенас В. Л. 2015. Амфибии и Рептилии. Алматы : Нур-принт. 135 с. (Сер. Животные Казахстана в фотографиях).

Boulenger G. A. 1893. Catalogue of the snakes in the British Museum (Natural history). Vol. I. Containing the families Typhlopidæ, Glauconiidæ, Boidæ, Ilysiidæ, Uropeltidæ, Xenopeltidæ, and Colubridæ Aglyphæ. London. XIII $+448+[\mathrm{XVIII}]+17 \mathrm{p}$.

Duméril A.-M.-C., Bibron G., Duméril A. 1854. Erpétologie Générale ou Histoire Naturelle Complète des Reptiles. Tome septième. Première partie. Comprenant l'histoire des Serpentes non venimeux. Paris : Librarie Enclyclopédique de Roret. VII+[5]+XVI+780 p.
Gmelin J. F. 1789. Caroli a Linné Systema Naturae. Ed. 13. Tom I. Pars III. Lipsiae : G. E. Beer. P. $1033-2224$.

Günter A. 1858. Catalogue of the colubrine snakes in the collection of the British Museum. London : Printed by of the Trustees. XVI+281+8 p.

Lantz L.-A. 1922. Révision des Reptiles décrits dans le «Journal de voyage» d'Iwan Lepechin // Bull. Soc. Zool. France. Vol. 47. P. 191 - 194.

Lichtenstein H., Martens E. 1856. Nomenclator reptilium et amphibiorum musei zoologici Berolinensis. Namenverziechniss der in der zoologischen Sammlung der Königlichen Universität zu Berlin aufgestellten Arten von Reptilien und Amphibien nach ihren Ordnungen, Familien und Gattungen. Berlin : Gedruckt in der Buchdrukerei der Königlichen Akademie der Wissenschaften. $48 \mathrm{~S}$.

Pallas P. S. 1799. Bemerkungen auf einer Reise in die südlichen Statthalterschaften des Russischen Reichs in den Jahren 1793 und 1794. Leipzig: G. Martini. Bd. 1. $516 \mathrm{~S}$.

Pallas P. S. [1814]. Zoographia Rosso-Asiatica, sistens omnium animalium in extenso Imperio Rossico et adjacentibus maribus observatorum recensionem, domicilia, mores et descriptiones, anatomen atque icones plurimorum; auctore Petro Pallas, eq. aur. Academico Petropoliano. Tomus III. Animalia monocardia seu frigidi sanguinis Imperii Rosso-Asiatici. Petropoli : in officina Caes. Academiae Scientarum. [2]+428+135 p.

Zhao Er-Mi, Adler K. 1993. Herpetology of China. Oxford, Ohio : Society for the Study of Amphibians and Reptiles. 522 p.

\section{Образец для цитирования:}

Ахмеденов К. М., Бакиев А. Г., Горелов Р. А., Назарова Г. А. 2019. Распространение, состояние и перспективы охраны каспийского полоза Hierophis caspius (Gmelin, 1789) (Colubridae, Reptilia) в Казахстане // Современная герпетология. Т. 19, вып. 1/2. C. 3 - 16. DOI: https://doi.org/10.18500/1814-6090-2019-19-1-2-3-16 


\title{
Distribution, Status and Prospects for the Conservation of the Caspian Whipsnake Hierophis Caspius (Gmelin, 1789) (Colubridae, Reptilia) in Kazakhstan
}

\author{
Kazhmurat M. Akhmedenov ${ }^{1}$, https://orcid.org/0000-0001-7294-0913; kazhmurat78@mail.ru, \\ Andrey G. Bakiev ${ }^{2}$, Roman A. Gorelov ${ }^{2}$, and Gulmira A. Nazarova ${ }^{1}$ \\ ${ }^{1}$ M. Utemisov West Kazakhstan State University \\ 162 N. Nazarbayev Av., Uralsk 090000, Kazakhstan \\ ${ }^{2}$ Institute of Ecology of the Volga Basin of the Russian Academy of Sciences \\ 10 Komzin St., Togliatti 445003, Russia \\ E-mail: herpetology@list.ru
}

Received 27 January 2019, revised 17 March 2019, accepted 27 April 2019

\begin{abstract}
The Caspian whipsnake was described by I. I. Lepyokhin (1771), possibly from the Western Kazakhstan. The species name caspius was assigned to the snake by J. F. Gmelin (1789). Based on our own and literature data, modern habitats of the Caspian whipsnake are given in the Western Kazakhstanian and Atyrau regions of Kazakhstan - from 48 $47.305^{\prime} \mathrm{N}$ and $47^{\circ} 22.559^{\prime} \mathrm{E}$ (in the north) to $46^{\circ} 56.536^{\prime} \mathrm{N}$ and $49^{\circ} 18.177^{\prime} \mathrm{E}$ (in the south). A number of findings noted over the past 250 years in modern Kurmangazinsky, Isatai and Makhambet districts of the Atyrau region, as well as in the vicinity of the Atyrau City, in Tupkaragan district of the Mangystau region, Akzhaik and Zhangalinsky districts of the Western Kazakhstan region require confirmation and clarification. Any indications of the distribution of the species in the Eastern Kazakhstan are erroneous. At present in the specially protected natural areas of Kazakhstan, the species reliably lives only in the natural state wildlife area "Orda" (of local value), where it was discovered in 2018. In order to preserve the species in Kazakhstan, the rationale and creation of a specially protected territory "Maloye Bogdo Mountain" seem promising. Rare plant and animal species, including the Caspian whipsnake with a relatively high abundance, inhabit this mountain and its surroundings, where mining of nonmetallic minerals has begun.
\end{abstract}

Key words: snakes, Red Data Book of the Republic of Kazakhstan, Maloye Bogdo, natural state wildlife area "Orda" (of local value).

DOI: https://doi.org/10.18500/1814-6090-2019-19-1-2-3-16

\section{REFERENCES}

Ananjeva N. B., Orlov N. L., Khalikov R. G., Darevsky I. S., Ryabov S. A., Barabanov A. V. Colored Atlas of the Reptiles of the North Eurasia (Taxonomic Diversity, Distribution, Conservation Status). St. Petersburg, Zool. Institute of RAS Publ., 2004. 232 p. (in Russian).

Akhmedenov K. M., Bakiev A. G., Gorelov R. A., Kalmykova O. G. To the Herpetofauna of the Region of the Maloe Bogdo Mountain. Izvestia of Samara Scientific Center of the Russian Academy of Sciences, 2017 a, vol. 19, no. 5, pp. 134-139 (in Russian).

Akhmedenov K. M., Bakiev A. G., Gorelov R. A., Kalmykova O. G., Klenina A. A. Gerpetofauna gor Bol'shogo i Malogo Bogdo i ikh okrestnostey: istoriya izucheniya, sovremennyy sostav i perspektivy sokhraneniya [The herpetofauna of the Bolshoye and Maloye Bogdo mountains and their surroundings: history of study, modern composition and conservation prospects]. In: Okhrana prirody i regional'noe razvitie: garmoniya i konflikty ( $k$ Godu ehkologii $v$ Rossii): materialy mezhdunar. nauch.-prakt. konf. $i$ shk.-seminara molodykh uchenykh-stepevedov "Geoehkologicheskie problemy stepnykh regionov", provedyonnykh $v$ ramkakh XXI sessii Obedinennogo nauch- nogo soveta po fundamental'nym geogra-ficheskim problemam pri Mezhdunar. assotsiatsii aka-demij nauk (MAAN) i Nauchnogo soveta RAN po fundamental'nym geograficheskim problemam [Conservation of nature and regional development: harmony and conflicts (to the Year of Ecology in Russia): materials of the international scientific-practical conference and school-seminar of young steppe scientists "Geoecological problems of steppe regions" held in the framework of the XXI session of the Joint Scientific Council on fundamental geographical problems International Native Association of Academies of Sciences (IAAS) and the Scientific Council on fundamental geographical problems. Vol. I]. Orenburg, Steppe Institute of the Ural Branch of the Russian Academy of Sciences Publ., 2017 b, pp. 113-117 (in Russian).

Akhmedenov K. M., Abuova R. S., Nazarova G. A. Supplements to the herpetofauna of the Maloye Bogdo mountain and its environs. Bulletin of West Kazakhstan State University, 2018 a, no. 3, pp. 285-296 (in Russian).

Akhmedenov K. M., Bakiev A. G., Gorelov R. A., Kalmykova O. G., Shpigelman M. I., Abuova R. S. Materials for the creation of a specially protected natural area "Mountain Maloe Bogdo" in Western Kazakhstan. Astra- 
khan Messenger Environmental Education, 2018 b, no. 5, pp. 18-26 (in Russian).

Akhmedenov K. M., Bakiev A. G., Efimov V. M., Kuvovenko A. E., Khaidarov E. E., Shpigelman M. I. Inder - perspektivnyy geopark Priural'ya: Dnevnik mezhdunarodnoy nauchno-poznavatel'noy ekspeditsii $v$ ramkakh programmy «Rukhani zhaygyru» i 55-letiya Zapadno-Kazakhstanskogo agrarno-tekhnicheskogo universiteta imeni Zhangir khana [Inder - Promising Geopark of the Ural: Diary of an International Scientific and Educational Expedition Under the Program "Spiritual renewal" and the 55th anniversary of the West Kazakhstan Agrarian Technical University named after Zhangir Khan]. Uralsk, West Kazakhstan Agrarian-Technical University named after Zhangir Khan Publ., 2018 c. 118 p. (in Russian).

Baydulova L., Bulatova K., Karagoyshin J. Zhivotnyy mir Zapadno-Kazakhstanskoy oblasti. Uchebnoye posobiye dlya uchashchikhsya obshcheobrazovatel'nykh shkol Zapadno-Kazakhstanskoy oblasti [Animal world of the West Kazakhstan region. A manual for students of secondary schools in the West Kazakhstan region]. Uralsk, 2001. 124 p. (in Russian).

Bannikov A. G., Darevsky I. S., Rustamov A. K. Zemnovodnyye i presmykayushchiyesya SSSR [Amphibians and Reptiles of the USSR]. Moscow, Mysl' Publ., 1971. 303 p. (in Russian).

Bannikov A. G., Darevsky I. S., Ischchenko V. G., Rustamov A. K., Szczerbak N. N. Opredelitel' zemnovodnykh i presmykaiushchikhsia fauny SSSR [Guide to Amphibians and Reptiles of the USSR Fauna]. Moscow, Prosvetscheniye Publ., 1977. 416 p. (in Russian).

Borkin L. J. Kto takoy Ivan? (kur'yeznyy sluchay iz istorii gerpetologii) [Who was Ivan? (an amusing story from the history of herpetology)]. In: Russko-nemetskiye svyazi v biologii $i$ meditsine: opyt 300-letnego vzaimodeystviya [Russian-German Links in Biology and Medicine: 300 year Experience of Interaction]. St. Petersburg, Sankt-Peterburgskij soyuz uchenykh, 2000, pp. 191-200. (in Russian).

Borkin L. J., Gannibal B. K., Golubev A. V. Dorogami Petra Simona Pallasa (po zapadu Kazakhstana) [On the parhways of Peter Simon Pallas (journeys through Western Kazakhstan)]. St. Petersburg, Uralsk, Evrazijskij soyuz uchyonykh Publ., 2014. 312 p. (in Russian).

Borkin L. J., Litvinchuk S. N. Gerpetologicheskiye issledovaniya na zapade Kazakhstana: P. S. Pallas $i$ sovremennost' [Herpetological field research in the western part of Kazakhstan: Peter Simon Pallas and present]. In: Priroda zapadnogo Kazakhstana i Peter Simon Pallas (polevyye issledovaniya 2012 goda) [The Nature of Western Kazakhstan and Peter Simon Pallas (field research 2012)]. St. Petersburg, Europeisky Dom Publ., 2015, pp. 53-79 (in Russian).

Brushko Z. K., Zima Yu. A. Sarıqursaq abjılan. Zheltobryukhiy poloz Coluber caspius Gmelin, 1779 [Whipsnake Coluber caspius Gmelin, 1779]. In: Krasnaya kniga Respubliki Kazakhstan. T. 1. Zhivotnyye;
Chast' 1: Pozvonochnyye. Izdaniye 4. [The Red Book of the Republic of Kazakhstan. Ed. 4th. Vol. 1: Animals; Part 1: Vertebrates]. Almaty, 2010, pp. 78-79 (in Kazakh and Russian).

Vasiliev I. To the knowledge of the fauna and biology of reptiles of Mangishlak. Lyubitel' prirody, 1914, vol. 9, no. 4, pp. 97-107 (in Russian).

Grebelsky S. G. Faunistic and environmental observations in the desert stations of the Mangyshlak peninsula based on materials from the expedition of 1936. Proceedings of the Military Medical Academy of the Workers' and Peasants Red Army named after S. M. Kirov, 1939, vol. 18, pp. 199-227 (in Russian).

Dvigubsky I. Opyt yestestvennoy istorii vsekh zhivotnykh Rossiyskoy Imperii. [Tom 4]. Gady, ili zhivotnyye presmykayushchiyesya [Experience of the natural history of all animals of the Russian Empire [Vol. 4]. Reptiles]. Moscow, Universitetskaya Tipografiya, 1832. 48 p. (in Russian).

Debelo P. V., Chibilyov A. A. Amfibii i reptilii Uralo-Kaspiyskogo regiona. Ser.: Prirodnoye raznoobraziye Uralo-Kaspiyskogo regiona. [Amphibians and reptiles of the Ural-Caspian region. Ser .: Natural diversity of the Ural-Caspian region]. Yekaterinburg, Ural Branch of Russian Academiy of Sciences Publ., vol. 3, 2013. 400 p. (in Russian).

Duysebaeva T. N., Chirikova M. A., Zima Yu. A., Belyalov O. V., Kovalenko A. V. Novyye dannyye o rasprostranennosti amfibiy $i$ reptiliy $v$ Kazakhstane: obzor po pervomu desyatiletiyu XXI veka [New data on the prevalence of amphibians and reptiles in Kazakhstan: a review of the first decade of the 21 st century]. In: Gerpetologicheskiye issledovaniya $v$ Kazakhstane $i$ sopredel'nykh stranakh: Sbornik nauchnykh statey [Herpetological studies in Kazakhstan and neighboring countries: Collection of scientific articles]. Alamaty, ASBK SOPK Publ., 2010, pp. 84-99 (in Russian).

Dunaev E. A., Orlova V. F. Snakes of the Russian Fauna. Field Guide. Moscow, Fiton XXI Publ., 2014. 120 p. (in Russian).

Dunaev E. A., Orlova V. F. Zemnovodnyye $i$ presmykayushchiyesya Rossii. Atlas-opredelitel'. Izdaniye 2-ye, pererabotannoye $i$ dopolnennoye [Amphibians and Reptiles of Russia. Atlas and determinant. 2nd ed., revised and enlarged]. Moscow, Fiton XXI Publ., 2017. 328 p. (in Russian).

Karelin G. S. Travels of G. S. Karelin across the Caspian Sea. Memoirs Imperial Russian Geographical Society, 1883, vol. 10, VI +497 p., 6 sheets of cards (in Russian).

Kessler K. F. Notes on lizards and snakes collected by I. B. Auerbach on Bolshoi Bogdo Mountain, during a journey of 1854 , compiled by K. F. Kessler, in 1858. Memoirs Imperial Russian Geographical Society on General Geography, 1871, vol. IV, pp. 69-75 (in Russian).

Krasnaya kniga Respubliki Kazakhstan. T. 1. Zhivotnyye; Chast' 1: Pozvonochnyye. Izdaniye 4. [The Red 


\section{РАСПРОСТРАНЕНИЕ, СОСТОЯНИЕ И ПЕРСПЕКТИВЫ ОХРАНЫ КАСПИЙСКОГО ПОЛОЗА}

Book of the Republic of Kazakhstan. Ed. 4th. Vol. 1: Animals; Part 1: Vertebrates]. Almaty, 2010. 324 p. (in Kazakh and Russian).

Kuzmin S. L., Semenov D. V. Konspekt fauny zemnovodnykh i presmykayushchikhsya Rossii [Synopsis of the Fauna of Amphibians and Reptiles of Russia]. Moscow, KMK Scientific Press Ltd., 2006. 139 p. (in Russian).

Lepekhin I. I. The travel notes of the doctor and the Academy of Sciences adjunct Ivan Lepekhin in various provinces of the Russian state in 1768 and 1769 [Part 1]. St. Petersburg, 1771. [VIII] +538 p. (in Russian).

Neruchev V. V., Arzhenkova N. G., Shatilovich O. A. Gerpetofauna rechnykh dolin severnogo Prikaspiya [Herpetofauna of the river valleys of the northern Caspian Sea]. In: Nazemnyye $i$ vodnyye ekosistemy: Mezhvuzovskiy sbornik [Land and aquatic ecosystems: Interuniversity collection]. Gorky, Izdatel'stvo Gorky State University, 1990, pp. 26- 33 (in Russian).

Neruchev V. V., Vasiliev N. F. The fauna of reptiles (Reptilia) of the North-Eastern Caspian Sea. Vestnik zoologii, 1978, no. 6, pp. 36-41 (in Russian).

Nikolsky A. M. Reptiles and Amphibians of the Russian Empire (Herpetologia Rossica). Notes of the Imperial Academy of Sciences, VIII Series, Physics and Mathematics Department, 1905, vol. XVII, no. 1. 518 p. (in Russian).

Nikolsky A. M. Opredelitel' presmykayushchikhsya $i$ zemnovodnykh Rossiyskoy Imperii [Guide to Reptiles and Amphibians of the Russian Empire]. Kharkov, Russkaia Tipografiia i Litografiia Publ., 1907. 182 p. (in Russian).

Nikolsky A. M. Fauna of Russia and Adjacent countries. Reptilia. Vol. II. Ophidia. Petrograd, Tipografiia Imperatorskoi Akademii Nauk, 1916. 350 p. (in Russian).

Ostrovskikh S. V., Pestov M. V., Shaposhnikov A. V. On a question of the Caspian Racer, Hierophis caspius (Gmelin, 1789), distribution in between of Volga and Ural Rivers. In: Gerpetologicheskiye issledovaniya v $\mathrm{Ka}$ zakhstane i sopredel'nykh stranakh [Herpetological Studies in Kazakhstan and neighboring countries]. Alamaty, Association for the Conservation of Biodiversity of Kazakhstan Publ., 2010, pp. 252-254 (in Russian).

Pallas P. S. Zametki o puteshestvii v yuzhnyye namestnichestva Rossiyskoy Imperii v 1793 i 1794 godakh. Tom pervyy (izbrannoye). Perevod s nemetskogo [Notes on the Journey to the Southern Governorship of the Russian Empire in 1793 and 1794. Vol. I (selected). Translation from German]. Astrakhan, Izdat.-poligraf. kompleks "Volga", 2008. 304 p. (in Russian).

Paraskiv K. P. Presmykaiushchiesia Kazakhstana [The Reptiles of Kazakhstan]. Alma-Ata, AN KazSSR Publ., 1956. 228 p. (in Russian).

Paraskiv K. P., Butovskiy P. M. On the Fauna of Amphibians and Reptiles of Western Kazakhstan. Proceedings of the Institute of Zoology of the Academy of Sciences of the Kazakh SSR, 1960, vol. 13, pp. 148-159. (in Russian).
Pasport gosudarstvennogo prirodnogo zakaznika mestnogo znacheniya "ORDA”. Utverzhdon prikazom Upravleniya prirodnykh resursov $i$ regulirovaniya prirodopol'zovaniya Zapadno-Kazakhstanskoy oblasti ot 25 noyabrya 2010 goda № 86 [The Passport of the State Natural Reserve of Local Value "ORDA". Approved by order of the Office of Natural Resources and Environmental Management of the West Kazakhstan region dated November 25, 2010, no. 86]. Uralsk, 2012. 7 p. (in Russian).

Petrenko A. Z., Dzhubanov A. A., Fartushina M. M., Irkaliyeva R. M., Darbayeva T. Ye., Kol'chenko O. T., Chernyshov D. M. Prirodno-resursnyy potentsial $i$ proyektiruyemyye ob'yekty zapovednogo fonda ZapadnoKazakhstanskoy oblasti [Natural Resource Potential and Designed Objects of the Reserve Fund West Kazakhstan region]. Uralsk, Zapadno-Kazahstanskiy gosudarstvennyy universitet Publ., 1998. 176 p. (in Russian).

Ravinskiy I. V. Khozyaystvennoye opisaniye Astrakhanskoy i Kavkazskoy Guberniy [Economic Description of the Astrakhan and Caucasian Provinces]. St. Petersburg, Imperatorskaia Tipografiia Publ., 1809. [2]+VI+528+ XIV p. (in Russian).

Rall Yu. M. Ancient steppe «Bes-Chokho» in the Volga-Ural sands. Priroda, 1935, no. 4, pp. 55-60 (in Russian).

Rasprostraneniye amfibiy $i$ reptiliy, zanesennykh $v$ Krasnuyu knigu Kazakhstana i redkikh vidov ryb. Masshtab 1:7500000 [Distribution of amphibians and reptiles listed in the Red Book of Kazakhstan and rare fish species. Scale 1: 7,500,000]. In: Natsional'nyy atlas Respubliki Kazakhstan. T. 3. Okruzhayushchaya sreda i ekologiya [National Atlas of the Republic of Kazakhstan. Vol. 3. Environment and Ecology]. Almaty, Institute of Geography Publ., 2010, pp. 140 (in Russian).

Rustamov A. K., Shcherbak. N. N. Okhrana amfibiy $i$ reptiliy $v$ zapovednikakh Sredney Azii $i$ Kazakhstana [Conservation of Amphibians and Reptiles in the Reserves of Central Asia and Kazakhstan]. In: Amfibii $i$ reptilii zapovednykh territoriy [Amphibians and Reptiles of Protected Areas]. Moscow, CNIL Glavohoty RSFSR Publ., 1987, pp. 101-118 (in Russian).

Sarayev F. A., Pestov M. V. To the Cadastre of Reptiles of the Northern and Northeast Caspian Sea. In: Gerpetologicheskiye issledovaniya v Kazakhstane $i$ sopredel'nykh stranakh: Sbornik nauchnykh statey [Herpetological Studies in Kazakhstan and neighboring countries]. Alamaty, Association for the Conservation of Biodiversity of Kazakhstan Publ., 2010, pp. 174-193 (in Russian).

Terentyev P. V., Chernov S. A. Kratkiy opredelitel zemnovodnykh i presmykayushchikhsya SSSR [A brief determinant of amphibians and reptiles of the USSR]. Moscow, Leningrad, Uchpedgiz Publ., 1936. 96 p. (in Russian).

Terentyev P. V., Chernov S. A. Opredelitel zemnovodnykh i presmykayushchikhsya [The determinant of amphibians and reptiles]. Moscow, Sovetskaya nauka Publ., 1949. 340 p. (in Russian). 
Tuniyev B. S., Orlov N. L., Ananyeva N. B., Agasyan A. L. Snakes of the Caucasus: Taxonomic Diversity, Distribution, Conservation. St. Petersburg, Moscow, KMK Scientific Press Ltd., 2009. 223 p. (in Russian).

Chernov S. A. Ecological-faunistic review of reptiles in the south of the Volga - Ural interfluve. Proceedings of the Zoological Institute of the Academy of Sciences of the USSR, 1954, vol. XVI, pp. 137-158 (in Russian).

Chirikova M. A., Kazenas V. L. Amphibians and Reptiles. Almaty, Nur-print Publ., 2015. 135 p. Ser. "Animals of Kazakhstan in photos". (in Russian).

Boulenger G. A. Catalogue of the snakes in the British Museum (Natural history). Vol. I. Containing the families Typhlopidae, Glauconiida, Boidce, Ilysiidce, Uropeltidae, Xenopeltidae, and Colubridae Aglyphce. London, 1893. XIII+448+[XVIII]+17 p.

Duméril A.-M.-C., Bibron G., Duméril A. Erpétologie Générale ou Histoire Naturelle Complète des Reptiles. Tome septième. Première partie. Comprenant l'histoire des Serpentes non venimeux. Paris, Librarie Enclyclopédique de Roret, 1854. VII+[5]+XVI+780 p.

Gmelin J. F. Caroli a Linné Systema Naturae. Ed. 13.

Tom I. Pars III. Lipsiae, G. E. Beer, 1789. pp. 1033-2224.

Günter A. Catalogue of the colubrine snakes in the collection of the British Museum. London, Printed by of the Trustees, 1858. XVI+281+8 p.
Lantz L.-A. Révision des Reptiles décrits dans le «Journal de voyage» d'Iwan Lepechin. Bull. Soc. Zool. France, 1922, vol. 47, pp. 191-194.

Lichtenstein H., Martens E. Nomenclator reptilium et amphibiorum musei zoologici Berolinensis. Namenverziechniss der in der zoologischen Sammlung der Königlichen Universität zu Berlin aufgestellten Arten von Reptilien und Amphibien nach ihren Ordnungen, Familien und Gattungen. Berlin, Gedruckt in der Buchdrukerei der Königlichen Akademie der Wissenschaften, 1856. $48 \mathrm{~S}$.

Pallas P. S. Bemerkungen auf einer Reise in die südlichen Statthalterschaften des Russischen Reichs in den Jahren 1793 und 1794. Leipzig, G. Martini, 1799, Bd. 1. $516 \mathrm{~S}$.

Pallas P. S. Zoographia Rosso-Asiatica, sistens omnium animalium in extenso Imperio Rossico et adjacentibus maribus observatorum recensionem, domicilia, mores et descriptiones, anatomen atque icones plurimorum; auctore Petro Pallas, eq. aur. Academico Petropoliano. Tomus III. Animalia monocardia seu frigidi sanguinis Imperii Rosso-Asiatici. Petropoli, in officina Caes. Academiae Scientarum, [1814]. [2]+428+135 p.

Zhao Er-Mi, Adler K. Herpetology of China. Oxford, Ohio, Society for the Study of Amphibians and Reptiles, 1993. 522 p.

\section{Cite this article as:}

Akhmedenov K. M., Bakiev A. G., Gorelov R. A., Nazarova G. A. Distribution, Status and Prospects for the Conservation of the Caspian Whipsnake Hierophis Caspius (Gmelin, 1789) (Colubridae, Reptilia) in Kazakhstan. Current Studies in Herpetology, 2019, vol. 19, iss. 1-2, pp. 3-16 (in Russian). DOI: https://doi.org/10.18500/1814-6090-2019-19-1-2-3-16 